\title{
Upper Cisuralian palynology and palaeoclimate of Manuguru area Godavari basin, India and their global correlation
}

\author{
Pauline Sabina $K^{*}$ and NeERJa Jha \\ Birbal Sahni Institute of Palaeobotany, 53 University Road, Lucknow 226 007, India. \\ ${ }^{*}$ Corresponding author.e-mail: paulinesabina@gmail.com
}

The Permian system of the Palaeozoic Erathem is divided into three series, the Early Permian Cisuralian Series, the Middle Permian Guadalupian Series, and the Late Permian Lopingian Series. The Cisuralian Series encompasses the Asselian to Kungurian stages which constitute the basal part of the Gondwana supersequence I. In India, they are represented lithostratigraphically by the Talchir, Karharbari, and Barakar formations. This paper presents the palynological results from the Barakar Formation of the Upper Cisuralian Series from Manuguru which lies in the southeastern part of the Godavari basin. The succession studied comprises 35 subsurface samples from bore hole 1007 represented by clay, shale, sandstone, and coal. The palynofloras in this sequence have a homogenous composition demonstrating that not many significant floral changes took place through the considered stratigraphic range. The entire sequence is characterized by the dominance of nonstriate bisaccate genus Scheuringipollenites and subdominance of striate bisaccate genus Faunipollenites (=Protohaploxypinus). The other pollen genera among the nonstriate bisaccates are Rhizomaspora, Primuspollenites, Ibisporites, and Platysaccus. The striate bisaccates include Striatites, Striatopodocarpites, and Stroterosporites. The taeniate taxa are represented by Lueckisporites and Lunatisporites. The common monosaccate genera include Caheniasaccites, Potoniesporites, and Barakarites. Spores are less common and include Latosporites, Brevitriletes, Horriditriletes, Microbaculispora, and Callumispora. They characterize the palynofloral composition of the Lower Barakar Formation. The correlation of this assemblage with some of the biostratigraphic palynozones proposed previously for the Cisuralian sequences of the Paraná Basin of South America, Kalahari Karoo Basin of South Africa, Ruhuhu Basin of Tanzania, East Africa as well as palynoassemblages from South Victoria Land and Dronning Maud Land, Antarctica and Collie Basin of west Australia point out to their Early Permian (Late Sakmarian-Early Artinskian) age. Palynomorphs such as Botryococcus sp., Tetraporinia sp., Balmeela sp. and Leiosphaeridia sp. are also recorded which suggest that these sediments were deposited during post-glacial near shore, cool and humid environment.

\section{Introduction}

The Gondwana sediments of Wardha-Godavari Basin occur in a linear tract within the peninsular shield trending in a NW-SE direction for more than $600 \mathrm{~km}$, from north of Chandrapur $\left(19^{\circ} 57^{\prime} \mathrm{N} ; 7^{\circ} 17^{\prime} \mathrm{E}\right)$ in Maharashtra to south of
Aswaraopet $\left(17^{\circ} 15^{\prime} \mathrm{N} ; 80^{\circ} 00^{\prime} \mathrm{E}\right)$ in Andhra Pradesh (Raja Rao 1982). The Godavari Basin is further divided into four sub-basins, viz., from NW-SE Godavari sub-basin, Kothagudem sub-basin, Chintalapudi sub-basin and Krishna-Godavari coastal tract (figure 1a). The Krishna-Godavari coastal tract occurs transverse to the above three trending

Keywords. Palynology; Early Permian; lower Barakar; Manuguru; Godavari basin; correlation; palaeoclimate. 


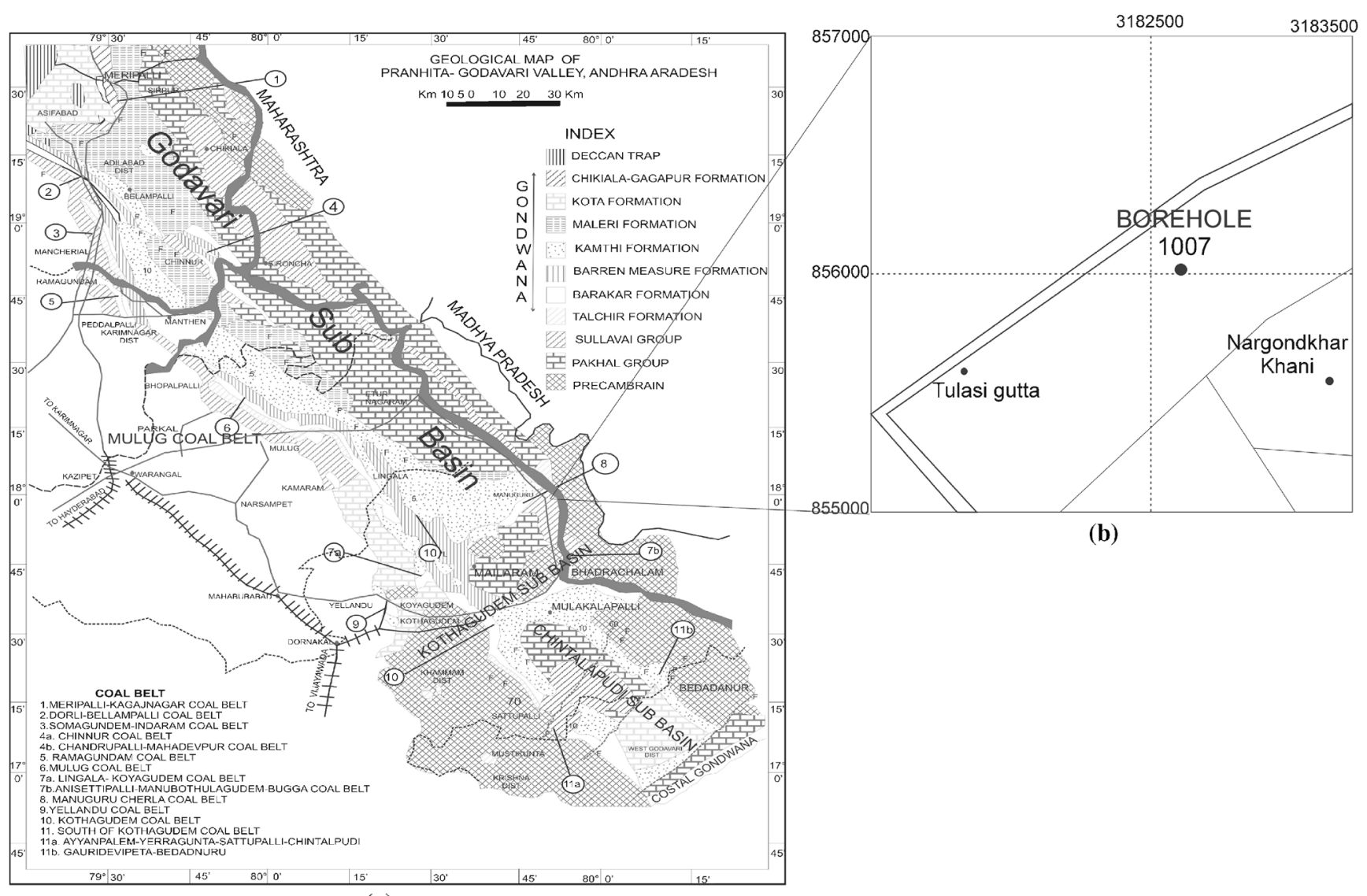

(a)

Figure 1. (a) Map of Godavari basin and (b) location map of Bore hole 1007 (after SCCL).

in an EW direction. The geology of these basins has been described by various workers (Blanford 1871; King 1881; Fox 1931; Kutty 1969; Sengupta 1970; Sastri et al. 1973; Srinivasa Rao et al. 1977; Raja Rao 1982; Raiverman et al. 1985; Lakshminarayana and Murti 1990; Lakshminarayana 1996; Ramanamurthy and Madhusudan Rao 1996). Studies covering various aspects of geophysics, sedimentology, and palaeontology are being carried out in this basin to resolve problems pertaining to age and depositional history of the basin. Further, with the finding of commercial coal within the basin (sensu Raja Rao 1982), scope was extended to carry out coal petrological and palynological studies in the basin due to the exploratory drilling programmes. Srivastava and Jha (1992a, 1993, 1995), Jha and Srivastava (1996), Jha (2006, 2008), Jha and Aggarwal (2010, 2011) and Jha et al. (2011) have contributed significantly to the palynological and biostratigraphic studies of the basin which has enabled exploration geologists in deciphering potential coal horizons within the Wardha-Godavari basin.

The present work deals with the palynological studies carried out in subsurface sediments of bore hole 1007 from Manuguru area of Godavari sub-basin (figure 1b). The existence of Permian palynoassemblages representing Lower and Upper Karharbari, Lower Barakar, Barren Measures, and Raniganj formations and Early Triassic palynoflora equivalent to that of Panchet Formation in Manuguru has been proved by palynological studies (Srivastava and Jha 1992b; Tewari and Jha 2006; Jha et al. 2011). In this paper, the results of the palynological studies of subsurface sediments from bore hole 1007 of Manuguru area are presented and used to determine the relative age and depositional environment of the investigated sequence.

\section{Geology}

Manuguru area lies in the Manuguru-Cherla coalbelt which is located in the southeastern part of the Godavari valley coalfield and extends over a stretch of $13 \mathrm{~km}$ from Godavari river on the northeast to Bugga in the southwest. The Gondwana sequence comprising of Talchir, Barakar, and Kamthi formations rests unconformably over the Precambrian Pakhal Formation. The PakhalGondwana contact appears to be faulted and the deposition of sediments is controlled by basement topography. The Talchir Formation is well developed in the eastern part of the area while in 
the rest of the area it is erratically distributed. The coal bearing Barakar Formation considerably varies in thickness along the dip and strike directions. The lithological succession in the area after Ramanamurthy and Madhusudan Rao (1996) is shown in table 1 .

\section{Material and methods}

Thirty five subsurface samples were collected from bore hole 1007 from Manuguru area drilled to

Table 1. Lithological succession in Manuguru area.

\begin{tabular}{ll}
\hline Age & \multicolumn{1}{c}{$\begin{array}{c}\text { Group/formation } \\
\text { (Ramanamurthy and } \\
\text { Madhusudan Rao 1996) }\end{array}$} \\
\hline Upper Triassic & $\begin{array}{l}\text { Maleri Formation } \\
\text { Lower Triassic } \\
\text { Upper Permian }\end{array}$ \\
Lower Permian & $\begin{array}{l}\text { Raniganj Formation } \\
\text { Barakar Formation }\end{array}$ \\
Upper Carboniferous/ & \\
Lower Permian & Talchir Formation \\
Precambrian & Sullavai Group \\
\hline
\end{tabular}

a depth of $172.00 \mathrm{~m}$ by the Singareni Collieries Company Ltd. (figure 2). Samples were processed by conventional palynological techniques which involve treatment with hydrochloric acid, hydrofluoric acid, and nitric acid. This was followed by alkali treatment. The materials were sieved through a 400 micra mesh and palynological slides were prepared using Canada balsam as mounting medium. The samples were studied with an Olympus BX 61 microscope. Photographs of palynomorphs were taken with DP-25 camera using Cell A software. The quantitative analysis is based on 200 specimens. Coordinates of the specimens are denoted by England Finder coordinates. The slides are housed at the Museum, Birbal Sahni Institute of Palaeobotany, Lucknow under catalogue numbers BSIP Slide No. 1495014958.

\section{Results of the palynological analysis}

The palynological content of the samples include 40 genera and 96 species. Among species 16 correspond to spores, 69 to pollen grains, 6 to costate grains and 5 belong to algae. The list of

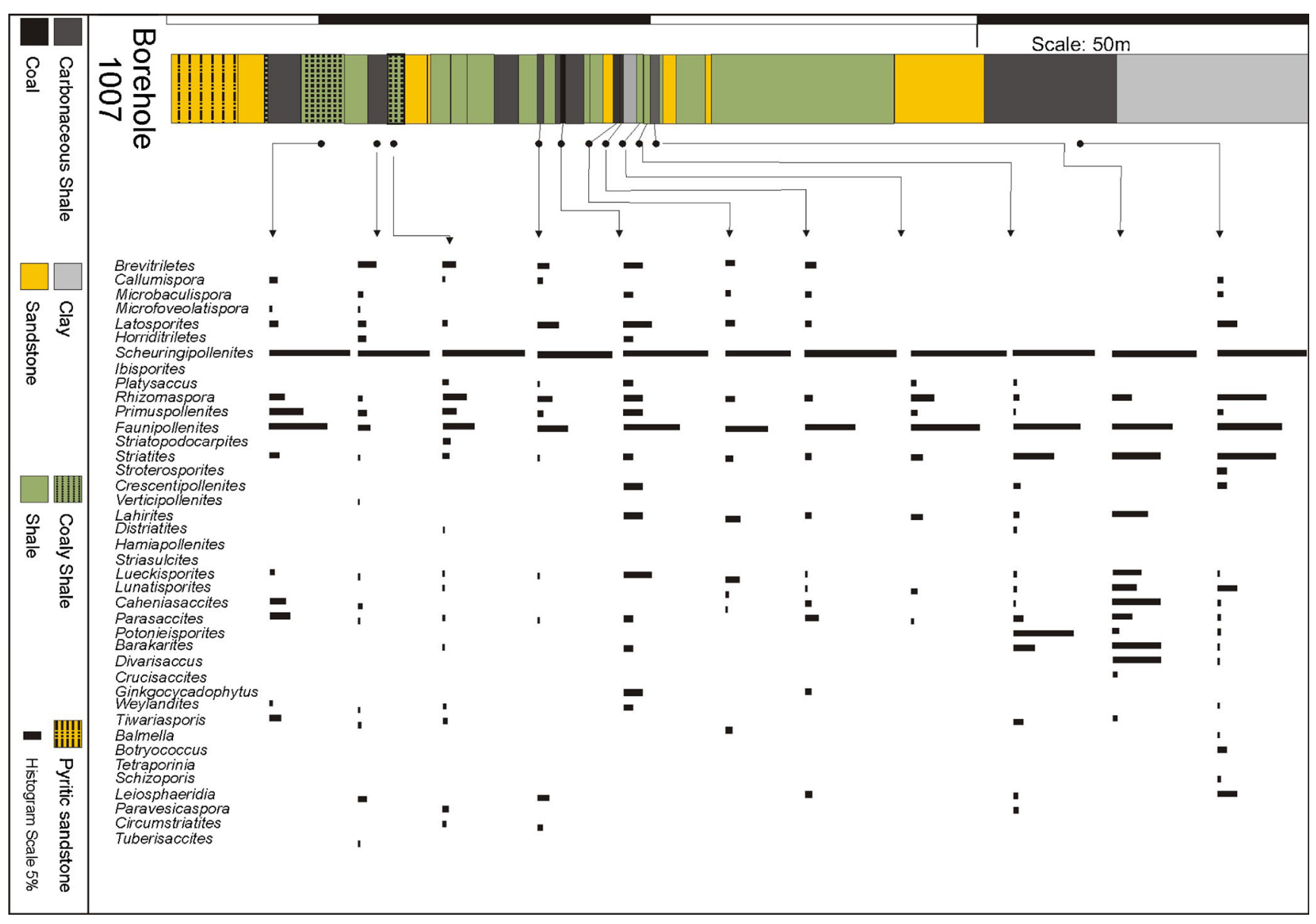

Figure 2. Litholog of Bore hole 1007 and histogram showing the distribution of taxa. 
Table 2. List of spores and pollen under their probable plant affinities.

\section{Spores \\ Sphenophyta}

Latosporites colliensis (Balme and Hennelly 1956) Venkatachala and Kar (1968)

Latosporites vulgaris or Laevigatosporites vulgaris (Ibrahim in Potonie, Ibrahim and Loose 1932) Ibrahim (1933)

\section{Pterophyta}

Horriditriletes filiformis (Balme and Hennelly) Backhouse (1991)

Horriditriletes ramosus (Balme and Hennelly) Bharadwaj and Salujha (1964)

Horriditriletes curvibaculosus Bharadwaj and Salujha (1964)

Lophotriletes novicus Singh (1964)

Lophotriletes rectus Bharadwaj and Salujha (1964)

Microbaculispora tentula Tiwari (1965)

Microbaculispora villosa (Balme and Hennelly) Bharadwaj (1962)

Brevitriletes unicus (Tiwari) Bharadwaj and Srivastava emend. Tiwari and Singh (1981)

Brevitriletes communis Bharadwaj and Srivastava emend. Tiwari and Singh (1981)

Callumispora barakarensis (Bharadwaj and Srivastava) Tiwari, Srivastava, Tripathi and Vijaya (1989)

Callumispora gretensis (Balme and Hennelly) Bharadawj and Srivastava emend. Tiwari (1977)

Microbaculispora tentula Tiwari (1965)

Microbaculispora villosa (Balme and Hennelly) Bharadwaj (1962)

Microfoveolatispora inidca Sinha (1972)

\section{Gymnosperms}

Monosaccate grains

Parasaccites korbaensis Bharadwaj and Tiwari (1964)

Parasaccites perfectus Bose and Maheshwari (1968)

Parasaccites obscures Tiwari (1965)

Parasaccites bilateralis Tiwari (1965)

Caheniasaccites flavatus Bose and Kar (1966)

Caheniasaccites elongates Bose and Kar (1966)

Caheniasaccites distinctus Lele and Makada (1972)

Caheniasaccites ovatus Bose and Kar (1966)

Potonieisporites neglectus Potonie and Lele (1961)

Potonieisporites congoensis Bose and Maheshwari (1968)

Potonieisporites lelei Maheshwari (1967)

Crucisaccites latisulcatus Lele and Maithy (1964)

Crucisaccites monoletus Maithy (1965)

Barakarites crassus Tiwari (1969)

Barakarites indicus Bharadwaj and Tiwari (1964)

Barakarites implicatus Tiwari (1965)

Barakarites triquetrus Tiwari (1965)

Divarisaccus lelei Venkatachala and Kar (1966)

Tuberisaccites jhingurdhahiensis Sinha (1972)

Circumstriatites obscurus Lele and Makada (1972)

\section{Nonstriate bisaccates}

Primuspollenites levis Tiwari (1964)

Primuspollenites brevicorpus Sinha (1972)

Scheuringipollenites ovatus (Balme and Hennelly) Foster (1975)

Scheuringipollenites maximus (Hart) Tiwari (1973)

Scheuringipollenites barakarensis (Tiwari) Tiwari (1973)

Scheuringipollenites tentulus (Tiwari) Tiwari (1973)

Platysaccus densicorpus Anand-Prakash (1972)

Platysaccus leschiki Hart (1960)

Vesicaspora luteus Salujha (1965)

Paravesicaspora indica (Tiwari) Bharadwaj and Tripathi (1981)

Ibisporites diplosaccus Tiwari (1968)

Ibisporites jhigurdhahiensis Sinha (1972) 
Table 2. (Continued).

Rhizomaspora indica Tiwari (1965)

Primuspollenites levis Tiwari (1964)

\title{
Striate bisaccates
}

Faunipollenites limpidus (Balme and Hennelly) Balme and Playford (1967)

Faunipollenites perexiguus (Bharadwaj and Salujha) Foster (1979)

Faunipollenites goraiensis (Potonié and Lele) Maithy (1965)

Faunipollenites amplus (Balme and Hennelly) Hart (1964)

Faunipollenites rugatus Segroves (1969)

Faunipollenites varius Bharadwaj (1962)

Striatopodocarpites fusus (Balme and Hennelly 1955) Potonie (1958)

Striatopodocarpites multistriatus Jha (1996)

Striatopodocarpites cancellatus (Balme and Hennelly 1955) Hart (1963)

Striatopodocarpites decorus Bharadwaj and Salujha (1964)

Striatites communis Bharadwaj and Salujha (1964)

Striatites varius Kar (1968)

Striatites rhombicus Bharadwaj and Salujha (1964)

Striatites multistriatus (Balme and Hennelly) Tiwari (1965)

Stroterosporites indicus Tiwari (1965)

Stroterosporites crassiletus Jha (1996)

Crescentipollenites fuscus (Bharadwaj) Bharadwaj, Tiwari and Kar (1974)

Crescentipollenites gondwanensis (Maheshwari) Bharadwaj, Tiwari and Kar (1974)

Crescentipollenites globosus (Maithy) Jha (1996)

Lahirites rarus Bharadwaj and Salujha (1964)

Lahirites incertus Bharadwaj and Salujha (1964)

Lahirites levicorpus Tiwari (1968)

Verticipollenites crassus Bharadwaj and Salujha (1964)

Verticipollenites debilis Venkatachala and Kar (1968)

Verticipollenites gibbosus Bharadwaj (1962)

Hamiapollenites karooensis (Hart) Hart (1964)

Hamiapollenites insolitus (Bharadwaj and Srivastava) Balme (1970)

Distriatites insolitus Bharadwaj and Salujha (1964)

Striasulcites tectus Venkatachala and Kar (1968)

Striasulcites ovatus Venkatachala and Kar (1968)

Lunatisporites pellucidus (Goubin 1965) Maheshwari and Banerji (1975)

Lunatisporites diffusus Bharadwaj and Tiwari (1977)

Lunatisporites ovatus (Goubin) Maheshwari and Banerji (1975)

Lueckisporites crassus Sinha (1972)

Lueckisporites nyakapendensis Hart (1960)

\section{Costate grains}

Weylandites lucifer (Bharadwaj and Salujha) Bharadwaj and Dwivedi (1981)

Weylandites magmus (Bose and Kar) Bharadwaj and Dwivedi (1981)

Tiwariasporis simplex (Tiwari) Maheshwari and Kar (1967)

Tiwariasporis gondwanensis (Tiwari) Maheshwari and Kar (1967)

Tiwariasporis flavatus (Tiwari) Maheshwari and Kar (1967)

Ginkgocycadophytus cymbatus (Balme and Hennelly) Potonie and Lele (1961)

\author{
Algae/probable algae \\ Botryococcus sp. \\ Schizoporis sp. \\ Tetraporinia sp. \\ Balmeela sp. \\ Leiosphaeridia sp.
}


spores and pollen under probable plant affinities is given in table 2. The botanical affinities are after Balme (1995).

\subsection{Assemblage analysis}

The distribution of species in different samples in the investigated sequence shows no significant floral changes through the considered stratigraphic range (figure 2). Apart from punctuated differences, no compositional turnover that persists through time was observed and therefore no distinct biohorizons could be established. Moreover, the genera that appear in a significant number of samples display the homogeneity of the assemblage compositions. Statistical analysis carried out in the studied succession reveals that the pollen grains are predominant over the spores. Among the pollen grains, the nonstriate bisaccate genus Scheuringipollenites (17-45\%) is the dominant taxon while the subdominant taxon is the striate bisaccate genus Faunipollenites (=Protohaploxypinus) (7-30\%). The other associated nonstriate bisaccate taxa which characterize the assemblage include species of Rhizomaspora (1-12\%), Primuspollenites (0.5-12\%), Paravesicaspora (1.5-2.5\%) and Platysaccus (1-2.5\%). The striate bisaccates are subdominant and are represented by species of Faunipollenites, Striatopodocarpites (0-3.5\%), Striatites (1-15\%), Stroterosporites (0-2.5\%), Crescentipollenites (2-5\%), Verticipollenites (0-0.5\%), Distriatites (0.5-1\%), Lahirites (1.5-7.5\%) while taeniate genera include Hamiapollenites (0-1\%), Lueckisporites (0.5-7.5\%) and Lunatisporites (0.5-5\%). Monosaccates are common, although not a dominant component of the assemblage and are represented by species of Caheniasaccites (0.5-10\%), Potonieisporites (1-18.5\%), Barakarites (0.5-10\%), Parasaccites (1-7.5\%), Crucisaccites (0-1\%), Divarisaccus (1-10\%), Circumstriatites (1.5-2.5\%) and Tuberisaccites (0-1\%). Spores include Brevitriletes (5-11\%), Horriditriletes (2-5\%), Callumispora (1-3\%), Lophotriletes (0-1\%), Microbaculispora (1-2.5\%), Microfoveolatispora $(0-1.5 \%)$ and Laevigatosporites (=Latosporites) (2$11.5 \%)$. Inaperturopollenites are represented by species of Weylandites (0.5-2.5\%) and Tiwariasporis (1-3.5\%). The stratigraphically significant taxa are illustrated in figure 3 .

\section{Biostratigraphic considerations and palynodating}

The international standard stages are largely erected based on marine fossils such as ammonoids, conodonts, and foraminifers (Christopher and Goodman 1996). But, in most of the Gondwana sequences there is a general lack of marine fossils; therefore, precise dating and correlation remains uncertain. Further, this is compounded by the problem of phytogeographic provincialism which resulted from the existence of distinct palaeoclimatic zones (ECL 1990). Consequently the age for the sequence at 1007 is deduced by comparison with other Gondwana palynofloras and thus remains tentative. The study reveals that the palynofloras have a homogenous composition throughout the succession indicating that for a period of time analysed there was no significant change in the composition of palaeoflora. Therefore all the samples are considered to pertain to a single assemblage, Scheuringipollenites + Faunipollenites assemblage. The palynoassemblage recorded from the sequence at bore hole 1007 of the present study displays characteristics which typify the palynoassemblage of Lower Permian Lower Barakar Formation. Comparison of this assemblage with other previous works both in India and across Gondwana indicate an Early Permian (Late Sakmarian-Early Artinskian) age.

\subsection{Palyno-correlation}

\subsubsection{India}

The Scheuringipollenites +Faunipollenites palynoassemblage recorded in the present study has been recorded from most of the Gondwana coalfields in India and therefore compare well with the sequence investigated in the present study. They include, the Godavari Coalfield (Srivastava and Jha 1989, 1992b, 1995; Jha and Aggarwal 2010, 2011, 2012), Giridih Coalfield (Srivastava 1973), Jharia Coalfield (Tripathi and Tiwari 1982), Johilla Coalfield (Anand-Prakash and Srivastava 1984), Wardha Coalfield (Bhattacharyya 1997; Mahesh et al. 2008, 2011), IB river Coalfield (Meena 2000), Sohagpur Coalfield (Ram-Awatar et al. 2003) and Bandar Coalfield (Pauline Sabina et al. 2007). The assemblages in all these coalfields are characterized by the dominance of Scheuringipollenites and subdominance of Faunipollenites in association with other taxa with minor discrepancies in their quantitative proportions of occurrence.

\subsubsection{Correlation with previous studies from other Gondwana regions (table 3)}

The Scheuringipollenites +Faunipollenites assemblage from the present study compares well with the Early Permian Protohaploxypinus zone of South Victoria Land (Kyle 1977). It occurs in the upper part of member A and ranges through members $\mathrm{B}$ and $\mathrm{C}$ of the Weller Coal Measures and is 

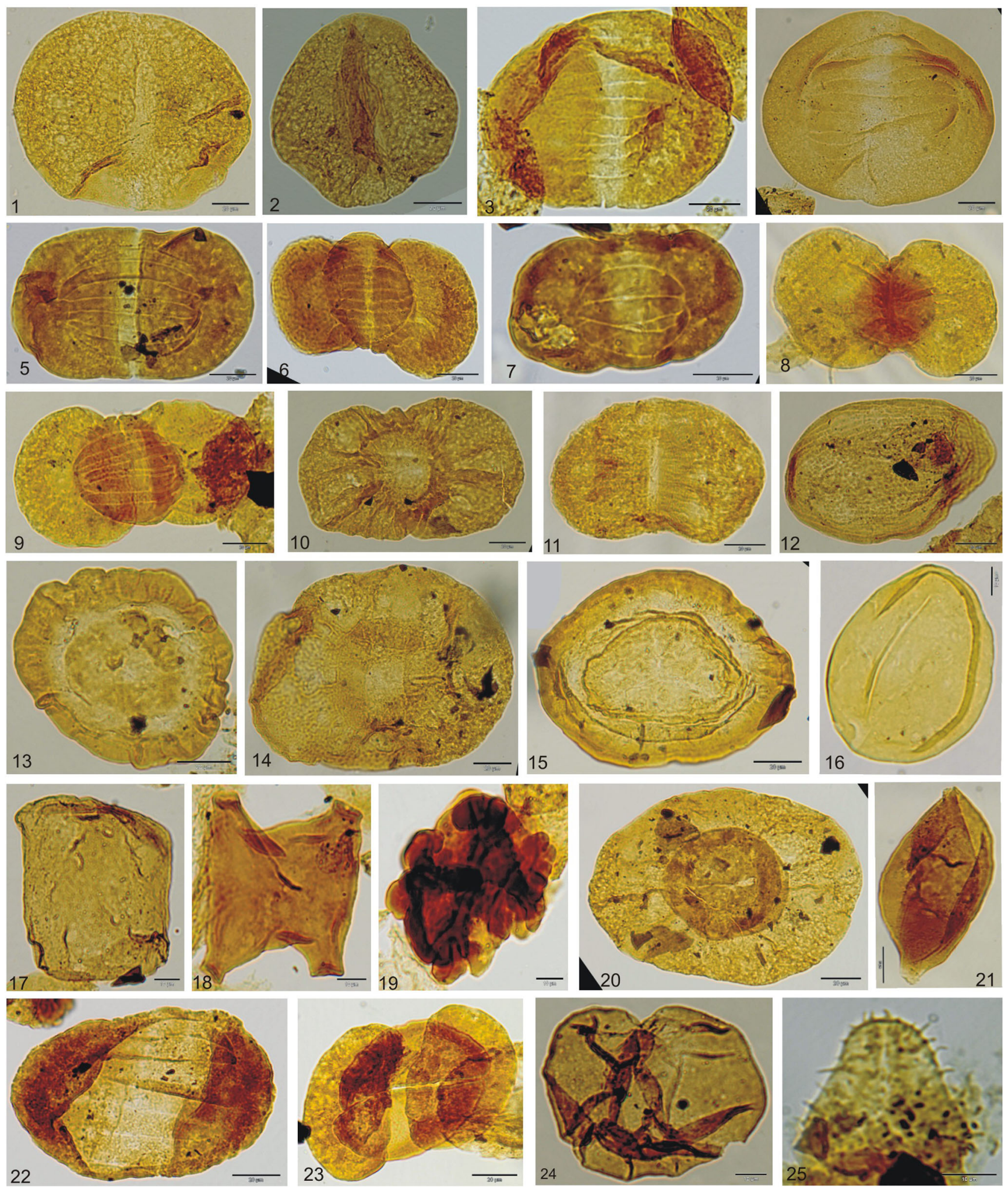

Figure 3. Stratigraphically significant taxa recorded in the present study.

characterized by the abundance of bisaccate pollen grains and low abundance of monosacate pollen grains. The investigated sequence also compares favourably with the assemblages recognised from
Vestfjella (Lindstrom 1995a) and Heimefrontfjella mountain ranges (Lindstrom 1995b) of Dronning Maud Land, Antarctica. The most significant taxa for comparison with the sequence at the Vestfjella 
Table 3. Correlation of the Scheurinipollenites/Faunipollenites assemblage of the present study with the zonation schemes from previous studies of selected Gondwana regions.

\begin{tabular}{|c|c|c|c|c|c|c|c|c|c|c|c|c|c|}
\hline & & $\begin{array}{l}\text { udy } \\
\text { le } 1007 \\
\text { ari } \\
\text { ndia }\end{array}$ & $\begin{array}{l}\text { Aus } \\
\text { Coll } \\
\text { (Ba }\end{array}$ & $\begin{array}{l}\text { alia } \\
\text { Basin } \\
\text { house 1991) }\end{array}$ & $\begin{array}{l}\text { Anta } \\
\text { Soutl } \\
\text { Victo } \\
\text { Land } \\
1977\end{array}$ & & $\begin{array}{l}\text { Eas } \\
\text { Sor } \\
\text { Tan } \\
200\end{array}$ & $\begin{array}{l}\text { Afri } \\
\text { swe- } \\
\text { ania } \\
\text { 3) }\end{array}$ & $\begin{array}{l}\text { Kawira coalfield, } \\
\text { (Semkiwa et al., }\end{array}$ & $\begin{array}{l}\text { Sou } \\
\text { Kal } \\
\text { Bas } \\
\text { anc } \\
(20\end{array}$ & $\begin{array}{l}\text { h Africa } \\
\text { hari Karoo } \\
\text { n (Modie } \\
\text { Le Hérissé } \\
\text { 9) }\end{array}$ & $\begin{array}{l}\text { Sou } \\
\text { Par } \\
\text { Toig }\end{array}$ & $\begin{array}{l}\text { America } \\
\text { 2005) }\end{array}$ \\
\hline 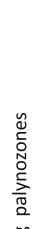 & 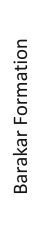 & 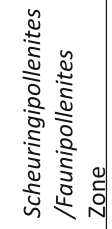 & 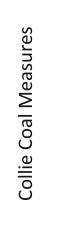 & $\begin{array}{l}\text { Praecolpatites } \\
\text { sinuosus Zone } \\
\text { (Base) }\end{array}$ & 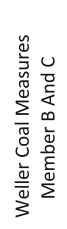 & 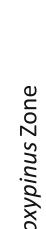 & $\stackrel{\circ}{\circ}$ & 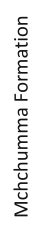 & $\begin{array}{l}\text { Scheuringipollenites } \\
\text { /Faunipollenites } \\
\text { Zone }\end{array}$ & 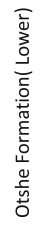 & KK 2 Zone & 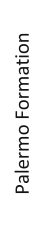 & $\begin{array}{l}\text { Lueckisporites virkkiae } \\
\text { Interval Zone (Base) }\end{array}$ \\
\hline 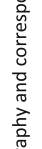 & 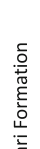 & & & $\begin{array}{l}\text { Striatopodocarpites } \\
\text { fusus Zone }\end{array}$ & & : & $\bar{u}$ & $\bar{\varpi}$ & & & $\begin{array}{l}\text { KK } 1 \text { Zone } \\
\text { (Upper half) }\end{array}$ & 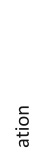 & $\begin{array}{l}\text { Hamiapollenites } \\
\text { karroensis Subzone }\end{array}$ \\
\hline 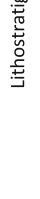 & 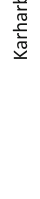 & & 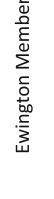 & & 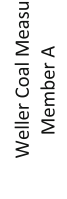 & & & 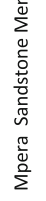 & & 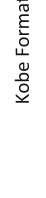 & & 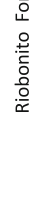 & \\
\hline
\end{tabular}

mountain-range include: Scheuringipollenites ovatus, Scheuringipollenites maximus, Laevigatosporites vulgaris, Lueckisporites spp., Striatopodocarpites fusus, Striatoabieites multistriatus, Weylandites lucifer, and Weylandites magnus. While with the assemblages from the Heimefrontfjella mountainrange, the investigated sequence from Manuguru can be correlated with the upper half of Locality A (Lindstrom 1995b) on the basis of common occurrence of taxa such as Scheuringipollenites ovatus, Scheuringipollenites maximus, Laevigatosprites vulgaris, Protohaploxypinus limpidus, Striatopodocarpites fusus, Striatoabieites multistriatus, and Weylandites magnus.

In Australia, a broad correlation can be made with the zonation scheme of Backhouse (1991) for the Collie basin of Australia. The assemblage from investigated sequence broadly correlates with the Striatopodocarpites fusus Zone of the Collie basin, the significant taxa that indicate a comparable range with the Striatopodocarpites fusus Zone to the lower part of the Praecolpatites sinuosus Zone of the Collie basin. The taxa pertinent for correlation of the two include Weylandites lucifer, Scheuringipollenites ovatus, Scheuringipollenites maximus, Protohaploxypinus limpidus, Horridtriletes teretangulatus, Laevigatosporites vulgaris, Cycadopites cymbatus, and Striatopodocarpites fusus.

In East Africa, the present assemblage shows distinct similarities with the ScheuringipollenitesProtohaploxypinus assemblage from the Lower Karoo sequence of the Songwe-Kiwira Coalfield in Tanzania (Semkiwa et al. 2003). The most significant taxa which favours their correlation include Alisporites ovatus (= Scheuringipollenites ovatus), Aliporites potoniei (=Scheuringipollenites maximus), Laevigatosporites spp. and Protohaploxypinus varius (=Faunipollenites varius), Protohaploxypinus perexiguus (=Faunipollenites perexiguus) and Weylandites lucifer.

In South Africa, the assemblage shows distinct similarities to those of the upper part of biozone KK1 and biozone KK2 of the Kalahari Karroo basin of Botswana, South Africa (Modie and Le Hérissé 2009). The taxa in the upper part of the biozone KK1 considered pertinent for correlation are Vittatina spp., Caheniasaccites flavatus, Cycadopites cymbatus, Protohaploxypinus rugatus, Potonieisporites congoensis, and Weylandites lucifer. While with the KK2 biozone, the sequence investigated shares the following species, Alisporites ovatus (= Scheuringipollenites ovatus), Aliporites potoniei (=Scheuringipollenites maximus), Laevigatosporites spp., Lophotriletes rectus, Protohaploxypinus varius (=Faunipollenites varius), Protohaploxypinus perexiguus (=Faunipollenites perexiguus) and Weylandites lucifer. Modie and Le Hérissé (2009) equated the upper part of biozone KK1 to the upper part of the Kobe Formation of the Ecca Group and the biozone KK2 to the lower part of the Otshe Formation of the Ecca Group. This comparison of the assemblage from the investigated sequence to the upper part of biozone KK1 and biozone KK2 broadly equates the Lower 
Barakar Formation to the Ecca Group which is of Sakmarian/Artinskian age. Modie and Le Hérissé (2009) compared the biozones KK2 and KK3 with Tiwari and Tripathi (1992) Assemblage zones III-VII.

With regard to the zonation proposed by Souza and Marques-Toigo (2003, 2005) for the Paraná basin in Brazil, South America, the assemblage studied shows similarities with the Hamiapollenites karooensis subzone and Lueckisporites virkkiae interval zone. The Hamiapollenites karooensis subzone is the upper part of the Vittatina costabilis interval zone. This zone is characterized by the dominance of bisaccate pollen grains and common taxa include Lueckisporites, Limitisporites, Vittatina, Scheuringipollenites, and Protohaploxypinus. Pollen taxa which characterize the Lueckisporites virkkiae interval zone are species of Protohaploxypinus, Striatopodocarpites, Striatoabieites, Lunatisporites, Marsupipollenites, which are the dominant components of this biozone. Monosaccate pollen grains Potonieisporites and Limitisporites are less common. The presence of these taxa in the investigated sequence broadly compares it to the Hamiapollenites karooensis subzone up to the base of the Lueckisporites virkkiae interval zone. Souza and Marques-Toigo (2003, 2005) equated the Hamiapollenites karooensis subzone to the upper part of the Rio Bonito Formation and the lower part of the Lueckisporites virkkiae interval zone to the Palermo and Irati formations of the Guata Group of the Paraná basin in Brazil which range in age from Late Sakmarian to Early Artinskian.

\section{Palaeoclimate}

During the Lower Gondwana sedimentation, the Gondwana basins of India witnessed varied climatic conditions due to its latitudinal position, continentality and relief. During the Permian, the palaeolatitudinal position of India was between $20^{\circ}$ and $45^{\circ} \mathrm{S}$ (Smith et al. 1981). As in other basins of the Gondwanaland, even in India initial sedimentation took place due to melting of glaciers. The glaciers on the Indian peninsula were not of continental sheet types as opined before but of isolated lobe type (Datta et al. 1983) originating from ice caps existing on highlands which favoured floral components to thrive on open lands which were free of ice. Tewari and Veevers (1993) proposed a model which postulates an East Antarctic palaeoupland from where the palaeo drainage system originated in a radial pattern. The Eastern Ghat highs were probably the nearest source of ice lobes for Talchir of Pranhita-Godavari and Cauvery basins in India (Vijaya 1996). In Pranhita-Godavari basin, the Lower Gondwana sedimentation commenced with the north-northwesterly radiation of glaciers from highlands at the southeastern end of the Godavari valley leading to the deposition of the Talchir tillite and the associated glaciofluvial sandstone and glaciolacustrine shale (Raja Rao 1982). This was followed by deglaciation in the Early Sakmarian which resulted in a eustatic sea level rise during the Late Sakmarian resulting in the inundation of sea water deep inside the Gondwanaland basins (Archbold 2001; Angiolini et al. 2005). The Leiosphaerids are the palynological indicators of this marine incursion, which is also manifested by the occurrence of Eurydesma and other marine fauna in Umaria and Manendragarh of Madhya Pradesh (Chandra et al. 1988).

Following the Sakmarian marine transgression, near shore environment prevailed with the advent of fluvial environment under periglacial climate (Chakraborty et al. 2003). The Lower Barakar Formation in India has been equated with these deposits (Mukhopadhyay et al. 2010) and hosts the major coal deposits. The presence of Balmeela sp., Tetraporinia sp. and Leiosphaeridia sp. in the sequence also indicates a near shore environment. Following the glacial retreat, there was amelioration in the climate resulting in a northwesterly flowing braided river system in the Godavari basin in which the Barakar and Kamthi sediments were deposited.

Cool-to-temperate condition prevailed during the early phase of Barakar sedimentation. According to Laskar and Mitra (1976), coal is formed both under hot humid tropical climate as well as in cold and temperate regions as the recent year's peat which is a precursor for coal. Therefore precipitation is the main prerequisite for the formation of coal, where the rainfall exceeds potential evaporation or evapotranspiration. Evidently, the flora which contributed to the coal formation lived in a damp climate, but not necessarily in the hot tropical climate. Therefore, cool temperate condition with high humidity may have persisted during the early phase of Lower Barakar Formation which has also been inferred through megafloral (Lele 1976) and palynological evidences (Tiwari and Tripathi 1987). Megafloristically the Gangomopteris flora is replaced with the Glossopteris flora with a diversification of species in comparison with the species in Karharbari Formation which also indicate amelioration from frigid cold climate to cool temperate climate in the Lower Barakar. Palynologically, Tiwari and Tripathi (1987) have recognised 11 climatic suites in the Lower Gondwana sequence, from the Lower Talchir (Early Permian) to the Lower Panchet (Lower Triassic) based on the cumulative abundance and sum total of the morphographic characters (see Tiwari and 
Tripathi 1987). The Suite-5 (A) indicates cool temperature with high humidity and is characterized by the dominance of Scheuringipollenites whose morphographic characters are characterized by thin central body, non-leathery saccus with haploxylonoid saccus construction. These morphographic characters are adapted for and infer cool climate with high humidity. The investigated sequence in bore hole 1007 is characterized by the dominance of Scheuringipollenites leading to the inference of prevalence of cool climatic conditions. The predominance of bisaccates over the monosaccates pollen also indicate amelioration from cold to cool conditions. This view supports the study by Suttner and Dutta (1986) who inferred a temperate, humid climate during Barakar on the basis of mineralogical studies and oxygen isotope studies. Therefore, deposition under cool temperate climate has been deduced for the sequence under study. Humidity is inferred by the proliferation of striate bisaccates, as striations are related with functions of temperature, water accumulation and harmomagathy (Tiwari and Tripathi 1987; Mahesh et al. 2008). Presence of minor coal seams in the investigated sequence also adds evidences for the prevalence of humid climate.

The sediments in bore hole 1007 are represented by coarse-grained sandstones, shales, and minor coal seams of a fluvial regime (Singh 1976), which may have formed as a consequence of melting of glaciers from high lands. Presence of Botryococcus sp. indicates freshwater to brackish environment which may have resulted from a significant increase of freshwater input from melting glaciers during deglaciation which in turn resulted in marine transgression due to eustatic sea level rise during Sakmarian. Marine incursion is further reflected by the presence of pyritic sandstone and palynomorphs such as Balmeela sp., Tetraporinia sp. and Leiosphaeridia sp. Mussels and fish facies in the Permian of the eastern limb of Godavari valley, at Manuguru (Chandra and Ghosh 1990) also indicate proximity to the sea.

\section{Conclusions}

In India, the Cisuralian Series is represented by the Talchir, Karharbari, and Barakar formations. The Talchir Formation is characterized by glacially influenced sedimentation while the Karharbari and Barakar formations are characterized by post-glacial near shore fluvial environments (Mukhopadhyay et al. 2010). The palynological studies carried out in the investigated sequence demonstrate a more or less homogenous composition throughout the stratigraphic range studied reflecting a relatively stable palaeo-plant community during the period of time recorded by these strata. The assemblage consists primarily of nonstriate bisaccates followed by striate bisaccates together with few monosaccates and few spores.

The palynoassemblage is characterized by the dominance of nonstriate bisaccate genus Scheuringipollenites and subdominance of striate bisaccate genus Faunipollenites (=Protohaploxypinus) which typify the palynoassemblage of Early Permian Lower Barakar Formation. The age for the sequence at 1007 is tentatively inferred as Early Permian (Late Sakmarian-Early Artinskian) age by comparison with other Gondwana palynofloras. Correlation with the assemblages from other parts of the former Gondwanaland are tentative and cannot be precise due to phytogeographic provincialism and variations in the ranges of certain taxa in different basins and also due to the basis on which the assemblage has been formulated by different workers. In the present study, the assemblage has been formulated taking into consideration the criteria of dominance and subdominance of taxa.

The assemblage from the bore hole 1007 correlates well with the palynoassemblages of the Lower Barakar Formation from most of the coalfields in peninsular India. Across Gondwana, they correlate best with the assemblage from SongweKiwira Coalfield of Tanzania, East Africa indicating that India and East Africa occupied the same palaeolatitudinal position during the Early Permian and therefore belong to the same phytogeographic province (Jha 2006). The present assemblage broadly correlates with the Early Permian assemblages from Dronning Maud Land, Antarctica, Collie basin of west Australia, Kalahari Karroo basin of Botswana, South Africa and the Paraná basin of South America. Due to variations in the ranges of taxa in different regions of Gondwana the assemblage has been dated to range between Late Sakmarian to Early Artinskian of the Early Permian System. Therefore, the succession in the bore hole 1007 from Manuguru of India is palynologically dated as Early Permian (Late Sakmarian-Early Artinskian) age.

A post-glacial, cool and humid near shore fluvial environment of deposition has been deduced on the basis of the lithological constituents of the sequence investigated which is represented by coarse grained pyritic sandstones, shales, and minor coal seams as well as palynomorphs such as Botryococcus sp., Tetraporinia sp., Balmeella sp., and Leiosphaeridia sp. The recovery of these palynomorphs from the post-glacial Lower Barakar sediments indicates relics of marine incursion during Sakmarian marine transgression persisting into Early Artinskian and proximity to the sea. 


\section{Acknowledgements}

The authors express their gratitude to the Director, BSIP for granting permission and making the needed facilities available to carry out this work. They are grateful to the authorities of the Singareni Collieries Company Limited (SCCL) Sri M Basavachari, Former GM (Exploration), Sri Murthy, GM (Exploration) and Y S Babu Rao, Incharge (Exploration division) and other members of the SCCL for their assistance.

\section{References}

Anand-Prakash and Srivastava S C 1984 Miofloral studies of the lower Gondwana sediments in Johilla coalfield, Madhya Pradesh, India; Palaeobotanist 32(3) 243-252.

Angiolini L, Brunton H and Gaetani M 2005 Early Permian (Asselian) Brachiopods from Karakorum (Pakistan) and their palaeobiogeographical significance; Palaeontology 48 69-86.

Archbold N W 2001 Pan-Gondwana, Early Permian (Asselian-Sakmarian-Artinskian) correlations; In: Contributions to Geology and Palaeontology of Gondwana in Honour of HelmutWopfner (ed.) Weiss R H, Geological Institute, University of Cologne, pp. 29-39.

Backhouse J 1991 Permian palynostratigraphy of the Collie basin, western Australia; Rev. Palaeobot. Palynol. $67237-314$.

Balme B E 1995 Fossil in situ spores and pollen grains: An annotated catalogue; Rev. Palaeobot. Palynol. 87 81-323.

Bhattacharyya A P 1997 Palynological recognition of the Karharbari-Barakar formations in the subsurface sediments of Wardha Coalfield, Maharashtra India; Palaeobotanist 46(1-2) 217-219.

Blanford W T 1871 A note on plant bearing sandstones of the Godavari on the southern extension of rocks belonging to Kamthi Group to the neighbourhood of Eluru and Rajahmundry on the possible occurrence of coal in the same directions; Rec. Geol. Surv. India 4(3) 59-88.

Chakraborty C, Mandal N and Ghosh S K 2003 Kinematics of the Gondwana basins of peninsular India; Tectonophys. 377 299-324.

Chandra S K and Ghosh D P 1990 Fish bearing facies in central Indian coal measures; Indian Mineral. 44(2) 203-210.

Chandra S K, Choudhury A and Ghosh D P 1988 Gondwana of Madhya Pradesh: Some aspects of stratigraphy and sedimentation; Indian Mineral. 42(1) 71-60.

Christopher R A and Goodman D K 1996 Introduction to biostratigraphy and time scales; In: Palynology: Principles and applications (eds) Jansonius J and Mcgregor D C, Am. Assoc. Stratigr. Palynol. Foundation 2 463-492.

Datta N R, Mitra N D and Bandyopadhyay N N 1983 Recent trends in the study of Gondwana basins of peninsular and extra-peninsular India; Petrol. Asia J., pp. 159-169.

Exploration Consultants Ltd 1990 Pan African Basin Study; Geological Survey of Botswana.

Fox C S 1931 Coal in India-II. The Gondwana system and related formations; Geol. Surv. India Memoir 58 1-128.

Jha N 2006 Permian palynology from India and Africa A phytogeographical paradigm; J. Palaeontol. Soc. India 51(1) $43-55$.

Jha N 2008 Permian-Triassic palynofloral transition in the Sattupalli area, Chintalapudi sub-basin, Godavari graben, Andhra Pradesh, India; J. Palaeontol. Soc. India 53(2) 159-168.

Jha N and Aggarwal N 2010 Early and Late Permian palynoflora from Lower Gondwana sediments of Gundala area, Godavari Graben, Andhra Pradesh, India; Palaeobotanist 59 71-80.

Jha N and Aggarwal N 2011 Palynological correlation of coal bearing horizons in Gundala area, Godavari graben, India; J. Earth Syst. Sci. 120(4) 663-679.

Jha N and Aggarwal N 2012 Permian-Triassic palynostratigraphy in Mailaram area, Godavari Graben, Andhra Pradesh, India; J. Earth Syst. Sci. 121(5) 1257-1285.

Jha N, Pauline Sabina K and Mehrotra N C 2011 Early Triassic palynomorphs from Manuguru area of Godavari Graben, Andhra Pradesh; J. Geol. Soc. India 78 167174.

Jha N and Srivastava S C 1996 Kamthi Formation palynofloral diversity; In: Gondwana Nine (eds) Guha P K S, Sengupta S, Ayyasami K and Ghosh R N (Calcutta: Oxford and IBH Publishing Co.), 1 355-368.

King W 1881 The geology of the Pranhita-Godavari Valley; Geol. Surv. India Memoir 18(3) 1-161.

Kutty T L 1969 Some contributions to the stratigraphy of the Upper Gondwana formations of the PranhitaGodavari valley, central India; J. Geol. Soc. India 10(1) 33-48.

Kyle R A 1977 Palynostratigraphy of the Victoria Group, south Victoria Land, Antarctica; NZ J. Geol. Geophys. 20 1081-1102.

Lakshminarayana G 1996 Stratigraphy and structural framework of the Gondwana sediments in the PranhitaGodavari Valley; In: Ninth International Gondwana Symposium, Hyderabad (eds) Guha P K S, Sengupta S, Ayyasami K and Ghosh R N, Geological Survey of India, Oxford and IBH Publishing Co., New Delhi-Calcutta, pp. 311-330.

Laksminarayana G and Murti K S 1990 Stratigraphy of the Gondwana Formations in the Chintalapudi sub-basin, Godavari Valley, Andhra Pradesh; J. Geol. Soc. India 36(1) 13-35.

Laskar B and Mitra N D 1976 Palaeoclimatic vicissitudes in India during Lower Gondwana sedimentation; Geophytology 6(2) 162-169.

Lele K M 1976 Palaeoclimatic implications of Gondwana floras; Geophytology 6(2) 207-229.

Lindstrom S 1995a Early Late Permian palynostratigraphy and palaeo-biogeography of Vestfjella, Dronning Maud Land, Antarctica; Rev. Palaeobot. Palynol. 86 157-173.

Lindstrom S 1995b Early Permian palynostratigraphy of the northern Heimefrontfjella mountain range, Dronning Maud Land, Antarctica; Rev. Palaeobot. Palynol. 89 359415.

Mahesh S, Pauline Sabina K and Mahesh Bilwa L 2008 Permian sediments from the subsurface sediments of Lower Gondwana of Wardha Valley Coalfield, Maharashtra, India; Gondwana Geol. Mag. 23(1) 63-67.

Mahesh S, Pauline Sabina K and Mahesh Bilwa L 2011 Palynodating and correlation of subsurface sediments from bore hole CMWY-95 of Wardha Valley Coalfield, Maharashtra, central India; Pal. Bot. 60 299-307.

Meena K L 2000 Palynodating of subsurface sediments of borehole IBH-6 in IB River Coalfield, Orissa, India; Geophytology 29(1-2) 111-113.

Modie B N and Le Hérissé A 2009 Late Palaeozoic palynomorph assemblages from the Karoo Supergroup and their potential for biostratigraphic correlation, Kalahari Karoo Basin, Bostwana; Bull. Geosci. 84(2) 337-358.

Mukhopadhyay G, Mukhopadhyay S K, Roychowdhury M and Parui P K 2010 Stratigraphic correlation between 
different Gondwana basins of India; J. Geol. Soc. India 76 251-266.

Pauline Sabina K, Mahesh Bilwa L and Mahesh S 2007 A palynostratigraphic study of Lower Gondwana sediments from Bandar Coalfield, Nagpur District, Maharashtra; J. Geol. Soc. India 69 834-840.

Raiverman V, Rao M R and Pal D 1985 Stratigraphy and structure of the Pranhita-Godavari Graben; Petrol. Asia J. 8(2) 174-189.

Raja Rao C S 1982 Coalfields of India: Vol. II, Coal resources of Tamil Nadu, Andhra Pradesh, Orissa and Maharashtra; Bull. Geol. Surv. India, Ser. A 4562 100.

Ramanamurthy B V and Madhusudan Rao C 1996 A new lithostratigraphic classification of Pranhita-Godavari basin with special reference to Ramagundam coal belt, Andhra Pradesh, India; In: Gondwana Nine, Vol. I (eds) Guha P K, et al., Oxford \& IBH Publ. Co., pp. 6778.

Ram-Awatar, Mukhopadhyay A and Adhikari S 2003 Palynostratigraphy of subsurface Lower Gondwana, Pali sediments, Sohagpur Coalfield, Madhya Pradesh; India Pal. Bot. 53 51-59.

Sastri V V, Sinha R N, Gurucharan Singh and Murty K V S 1973 Stratigraphy and tectonics of sedimentary basins on the east coast of peninsular India; Bull. Amer. Assoc. Petrol. Geol. 57(4) 655-678.

Semkiwa P, Kalkreuth W, Utting J, Mpanju F and Hagemann H 2003 The geology, petrology, palynology and geochemistry of Permian coal basins in Tanzania: 2. Sonwe-Kiwira Coalfield; Int. J. Coal Geol. 55 157186.

Sengupta S 1970 Gondwana sedimentation around Bheemaram, Pranhita-Godavari Valley, India; J. Sedim. Petrol. 40(1) 140-170.

Singh I B 1976 Mineralogical evidences for climatic vicissitudes in India during Gondwana times; Geophytology 6(2) 174-186.

Smith A G, Hurley A M and Briden J C 1981 Phanerozoic palaeocontinental world maps; Cambridge Univ. Press, Cambridge.

Souza P A and Marques-Toigo M 2003 An overview on the palynostratigraphy of the Upper Paleozoic strata of the Brazilian Paraná Basin; Rev. Mus. Arg. Cienc. 77 353-365.

Souza P A and Marques-Toigo M 2005 Progress on the palynostratigraphy of the Permian strata in Rio Grande do Sul State, Parana Basin, Brazil; Ann. Brazilian Acad. Sci. 77(2) 353-365.
Srinivasa Rao K, Subbaraju M, Md Khan I A and Srinivasarao T 1977 Sedimentation and tectonic evolution of parts of Godavari valley, Andhra Pradesh, India; Abst. IVth Int. Gond. Symp., Calcutta.

Srivastava S C 1973 Palynostratigraphy of the Giridih Coalfield; Geophytology 3(2) 184-194.

Srivastava S C and Jha N 1989 Palynostratigraphy of Lower Gondwana sediments in Godavari Graben, Andhra Pradesh, India; Palaeobotanist 37(22) 199-209.

Srivastava S C and Jha N 1992a Permian palynostratigraphy in Ramakrishnapuram area, Godavari Graben, Andhra Pradesh, India; Geophytology 20(2) 83-95.

Srivastava S C and Jha N 1992b Palynostratigraphy of Permian sediments in Manuguru area, Godavari Graben, Andhra Pradesh; Geophytology 22 103-110.

Srivastava S C and Jha N 1993 Palynostratigraphy of Lower Gondwana sediments in Chintalapudi sub-basin, Godavari Graben, Andhra Pradesh; Geophytology 23(1) 93-98.

Srivastava S C and Jha N 1995 Palynostratigraphy and correlation of Permian-Triassic sediments in Budharam area, Godavari Graben, India; J. Geol. Soc. India 46 $647-653$.

Suttner L J and Dutta P K 1986 Alluvial sandstone composition and palaeoclimate. II. Authegenic mineralogy; J. Sedim. Petrol. 56 346-358.

Tewari R and Jha N 2006 Occurrence of plant megaand microfossils from Barakar and Raniganj formations of Manuguru Area, Godavari Graben, Andhra Pradesh; J. Geol. Soc. India 67 101-112.

Tewari R C and Veevers J J 1993 Gondwana basins of India occupy the middle of a $7500 \mathrm{~km}$ sector of radial valleys and lobes in central-eastern Gondwanaland; 8th Proc. Gondwana Symp., Hobart, Australia.

Tiwari R S and Tripathi A 1987 Palynological zones and their climatic inference in the coal bearing Gondwana of peninsular India; Palaeobotanist 36 87-101.

Tiwari R S and Tripathi A 1992 Marker assemblage zones of spores and pollen species through Gondwana Palaeozoic and Mesozoic sequence in India; Palaeobotanist $\mathbf{4 0}$ $194-236$.

Tripathi A and Tiwari R S 1982 Barakar miofloral from Jharia Coalfield; Geophytology 12 195-200.

Vijaya 1996 Advent of Gondwana deposition on Indian peninsula: A palynological reflection and relationship; In: Ninth International Gondwana Symposium, Hyderabad (eds) Guha P K S, Sengupta S, Ayyasami K and Ghosh R N, Geological Survey of India, Oxford and IBH Publishing Co., New Delhi-Calcutta, pp. 283-298. 